\title{
Chemical defence against bacteria in the red alga Asparagopsis armata: linking structure with function
}

\author{
N. A. Paul ${ }^{1, *}$, R. de Nys ${ }^{2}$, P. D. Steinberg ${ }^{1}$ \\ ${ }^{1}$ School of Biological, Earth \& Environmental Sciences, and Centre for Marine Biofouling and Bio-Innovation, \\ University of New South Wales, Sydney 2052, Australia \\ ${ }^{2}$ School of Marine Biology and Aquaculture, James Cook University, Townsville 4811, Australia
}

\begin{abstract}
Although numerous algal products have antimicrobial activity, limited knowledge of metabolite localisation and presentation in algae has meant that ecological roles of algal natural products are not well understood. In this study, extracts of Asparagopsis armata had antibacterial activity against marine (Vibrio spp.) and biomedical (Escherichia coli, Pseudomonas aeruginosa and Staphylococcus spp.) strains. The major natural products in both life-history stages of $A$. armata (as determined by gas chromatography-mass spectrometry analysis [GC-MS]) were bromoform (0.58 to $4.3 \%$ of dry weight [DW]) and dibromoacetic acid [DBA] (0.02 to $2.6 \%$ DW), and each compound was active against these same bacteria. To resolve whether this antibiotic activity was ecologically relevant, we examined the localisation of metabolites in the specialised cells of $A$. armata and observed a delivery mechanism for the release of metabolites to the surface. Bromoform and DBA were subsequently quantified in the surrounding medium of laboratory cultures, establishing their release from the alga. In a novel ecological test of algal natural products, halogenated metabolites in $A$. armata were manipulated by omitting bromine from an artificial seawater medium. Significantly higher densities of epiphytic bacteria occurred on algae that no longer produced halogenated metabolites. Both bromoform and DBA were more active against bacteria isolated from algae lacking brominated metabolites than algae producing normal amounts of these compounds. Taken together, these results indicate that halogenated metabolites of A. armata may be important in reducing epiphytic bacterial densities.
\end{abstract}

KEY WORDS: Chemical defence · Antifouling · Algae · Bacteria · Gland cell · Bromoform · Dibromoacetic acid · Gas chromatography-mass spectrometry

Resale or republication not permitted without written consent of the publisher

\section{INTRODUCTION}

Marine pathogenic bacteria can have substantial impacts on algae (Littler \& Littler 1995, Correa \& Sanchez 1996, Kushmaro et al. 1997, Potin et al. 2002). Furthermore, epiphytic bacteria can indirectly lead to adverse effects, such as drag or reduced photosynthesis, by enhancing the settlement of macrofoulers (Wahl 1989). Yet despite the constant threat of bacterial epibiosis, many algae remain largely free of disease and heavy fouling (Correa \& Sanchez 1996, Potin et al. 2002). Such observations have encouraged widespread screening of algae for novel antimicrobial compounds (McConnell \& Fenical 1979). However, algae-derived antimicrobials have generally been tested by applying whole plants, crude extracts, or pure compounds to plated microorganisms, most of which have limited ecological relevance (Hornsey \& Hide 1974, Al-Ogily \& KnightJones 1977, Hellio et al. 2001). While these antimicrobial assays provide insight into potential functions for algal metabolites, their roles in mediating interactions with epiphytic bacteria are often unknown. 
The role of algal metabolites as inhibitors of surface colonisation (antifoulants) by macro- and microorganisms in a more ecological context has received renewed attention (reviewed by Steinberg \& de Nys 2002). In part, this increased focus is due to investigations of the localisation and delivery mechanisms of biologically-active secondary metabolites (Schmitt et al. 1995, de Nys et al. 1998, Dworjanyn et al. 1999). This is a crucial issue for surface active inhibitors, and the presentation of metabolites for chemical defence will ultimately depend on the nature of the structures in which these metabolites are produced and stored. However, few studies have examined the ecological roles of algal secondary metabolites in microbial antifouling at relevant surface concentrations (Kubanek et al. 2003).

In general, the production of biologically-active metabolites is inherently linked to an ability to partition compounds into specialised storage structures in order to avoid autotoxicity (McKey 1979). Storage structures of marine algae have long been proposed to contain materials that have ecological function (Kylin 1927). These specialised structures can be single cells, or components thereof, and have varied ultrastructure. They include gland cells (or vesicle cells), in which the vesicle occupies practically the entire cellular space (Young \& West 1979, Dworjanyn et al. 1999), and cells with refractile inclusions, such as corp en cerise (Young et al. 1980) and physodes (Schoenwaelder 2002). Most specialised storage cells are located at, or close to, the surface cell layer; however, not all algae have the means to deliver natural products to the surface (Young \& West 1979). Delivery is an essential criterion for surface-mediated interactions such as the inhibition of fouling by bacteria. The release of a metabolite to the algal surface and its demonstrated efficacy against sympatric bacteria represent the 2 major issues in distinguishing a natural antifoulant from other potentially bioactive metabolites.

We investigated the localisation of secondary metabolites in the red alga Asparagopsis armata and their role as natural inhibitors of the growth of marine bacteria. A. armata is a member of the Bonnemaisoniaceae, a family with well characterised chemistry (Fenical 1975). Over 100 halogenated compounds are found in the genus Asparagopsis alone, including haloforms, haloacids and haloketones (McConnell \& Fenical 1977, Woolard et al. 1979). The natural products of $A$. armata have been proposed to act in bacterial antifouling (Hornsey \& Hide 1974, McConnell \& Fenical 1979), although ecological tests against relevant bacteria have not been performed. While it is generally accepted that these halogenated metabolites are localised in specialised gland cells, or 'vesicle' cells, (Wolk 1968, Fenical 1975, McConnell \& Fenical
1977), the delivery and release of metabolites to the surface has not been determined. This needs to be demonstrated in order to confirm an ecological role as natural antifoulants.

We investigated how the natural products chemistry and morphology of Asparagopsis armata related to its antibacterial properties. More specifically we asked: (1) Do extracts of this alga inhibit bacterial growth? (2) What are the major metabolites in the 2 life-history stages of A. armata? (3) Where are these metabolites stored and are they released from the alga? (4) Do the metabolites of $A$. armata inhibit epiphytic bacteria? We also describe a novel test of the ecological roles for algal secondary metabolites by manipulating the production of these compounds in A. armata.

\section{MATERIALS AND METHODS}

Study organism. Asparagopsis armata Harvey has a heteromorphic life-history, alternating between a filamentous tetrasporophyte (diploid) and an erect, plumose gametophyte (haploid). The tetrasporophyte is often referred to in the literature as the Falkenbergiastage of $A$. armata, having once been described as a separate species. Both tetrasporophytes, and gametophytes, of $A$. armata were collected from the shallow subtidal at Bare Island $\left(33^{\circ} 59^{\prime} 38^{\prime} \mathrm{S}, 151^{\circ} 14^{\prime} 00^{\prime} \mathrm{E}\right)$, Sydney, Australia. At this site, the tetrasporophyte is found throughout the year, while the gametophyte is found only in late winter to summer.

Screening of algal extracts against known microorganisms. Tetrasporophytes and gametophytes of Asparagopsis armata were collected and transported back to the laboratory. Freeze-dried material was either extracted exhaustively in methanol $(\mathrm{MeOH})$ or in dichloromethane (DCM). These extracts were made up at $100 \mu \mathrm{g} \mathrm{l}^{-1}$ in diethyl-ether (DEE). MeOH and DCM extracts of $A$. armata were tested against 6 strains of bacteria; 2 marine (Vibrio harveyii, V. alginolyticus) and 4 biomedical strains (Pseudomonas aeruginosa, Staphylococcus aureus, S. epidermis and Escherichia coli). V. harveyii and $V$. alginolyticus were cultured in $37.4 \mathrm{~g} \mathrm{l}^{-1}$ Marine Broth (DIFCO ${ }^{\mathrm{TM}}$ ), while E. coli, S. aureus, S. epidermis and $P$. aeruginosa were cultured in $13 \mathrm{~g} \mathrm{l}^{-1}$ Nutrient Broth (OXOID). Broths were inoculated with plated strains of microorganisms and shake-incubated for $20 \mathrm{~h}$ at $30^{\circ} \mathrm{C}$. Broth aliquots of $150 \mu$ l were spread over 3 replicate agar plates $(1.5 \%$ agar-agar in the respective growth media) for each bacterial strain. Assays were performed by stab-inoculating $100 \mu \mathrm{g}$ of $\mathrm{MeOH}$ or DCM extract dissolved in DEE into the agar surface.

Whole pieces of tetrasporophyte were also tested against Chromobacterium violaceum (CV026). C. violaceum produces the pigment violacein, and mutants 
such as this can be used in assays of the regulation of bacterial signalling (Manefield et al. 1999). Growth plates were prepared with a synthetic acylated homoserine lactone (oxo-hexanoyl-homoserine lactone at $0.5 \mathrm{ng} \mathrm{ml}^{-1}$ of media), which regulates the production of violacein. While the signalling component was not assessed in this study, the C. violaceum assay was used as the absence of pigment is a clear means of determining inhibition of growth. Algae ( 50 mg fresh weight $[\mathrm{FW}]$ per piece) were placed on top of LB-10 (10 $\mathrm{g} \mathrm{l}^{-1} \mathrm{NaCl}, 5 \mathrm{~g} \mathrm{l}^{-1}$ yeast extract, $10 \mathrm{~g} \mathrm{l}^{-1}$ tryptone) agar plates. LB-10 agar $(0.6 \%$ agar) inoculated with C. violaceum was then poured until slightly covering the algal tissue.

In all antibacterial assays, the size $\left(\mathrm{cm}^{2}\right)$ of the activity zone surrounding the inoculation point of each treatment was measured. For the DCM extracts, each replicate bacterial strain $(n=3)$ had a single inoculate from both tetrasporophyte and gametophyte in a splitplot design. A comparison of the size of the activity zone against the 6 bacterial strains was made using a partially nested ANOVA, with Strain and Life Stage as fixed factors, and Plate nested in Strain. A direct comparison was not made between the $\mathrm{MeOH}$ and DCM extracts.

Chemical analysis of Asparagopsis armata. Quantitative analysis of the major halogenated metabolites of Asparagopsis armata was performed by gas chromatography-mass spectrometry (GC-MS). Ion fragments characteristic of the major compounds were: dibromochloromethane $\left(\mathrm{CHBr}_{2} \mathrm{Cl}\right)$ (molecular ion m/e 208 and $\mathrm{M}+-129)$; bromoform $\left(\mathrm{CHBr}_{3}\right)$ (molecular ion cluster at $m / e$ 250, 252, 254, 256 [1:2:2:1] and M+-173); bromochloroacetic acid (methyl ester) (molecular ion m/e 188 and M+ - 129); dibromoacetic acid (DBA) (methyl ester) (molecular ion cluster $m / e 230,232,234$ [1:2:1] and M+-173); 3, 3 dibromoacrylic acid (methyl ester) (molecular ion cluster $m / e$ 242, 244, 246 [1:2:1] and M+-213). Initial comparisons of extraction techniques (including drying method and solvent type) demonstrated that methanol extraction of freeze-dried material consistently yielded the highest amounts of the major halogenated metabolites. No qualitative differences in the above compounds were found when extracting from freezedried versus wet material. The presence of methyl esters of the compounds was an artefact of extraction in $\mathrm{MeOH}$, as EtOH extraction yielded ethyl esters of the same acids. This was determined by fragmentation patterns of the mass spectra and increases in retention times. Consequently, all haloacids were quantified using methyl esters as standards. There was no evidence of nonesterified haloacids in the samples.

To quantify the major metabolites, algae were freeze-dried, weighed and extracted in $\mathrm{MeOH}$ with $10 \mu \mathrm{g} \mathrm{ml}^{-1}$ naphthalene as an internal standard. The extraction volume was approximately $30 \mu \mathrm{l} \mathrm{MeOH}$ $\mathrm{mg}(\text { dry weight }[\mathrm{DW}])^{-1}$. $\mathrm{MeOH}$ was added to the tissue in the GC-MS inserts, sealed and then sonicated for approximately $15 \mathrm{~min}$. Samples were left at $-30^{\circ} \mathrm{C}$ for at least $72 \mathrm{~h}$ to ensure esterification before transfer by glass syringe into a clean GC-MS vial. $\mathrm{MeOH}$ extracts were directly quantified using GC-MS. Gas chromatography was performed using a Hewlett Packard (HP) 5890 series II gas chromatograph and a polyethyleneglycol-coated phase on a polyimide-coated fused silica capillary column (Sol-gel wax, $30 \mathrm{~m}, 0.25 \mathrm{~mm}$ i.d.). All injections $(2 \mu \mathrm{l})$ were performed in the splitless mode (1.5 min) with an inlet pressure of 8 psi. The inlet liner (4 mm i.d., $78.5 \times 6.3 \mathrm{~mm}$ o.d., single taper-SGE part no. 092018) was replaced after 50 samples. The injection port was held at $250^{\circ} \mathrm{C}$ and the GC-MS interface at $300^{\circ} \mathrm{C}$. The $\mathrm{GC}$ was held at $40^{\circ} \mathrm{C}$ for $1 \mathrm{~min}$, ramped at $16^{\circ} \mathrm{C} \mathrm{min}^{-1}$ to $250^{\circ} \mathrm{C}$, then held at this temperature for 2 min. Helium was used as the carrier gas. Mass spectrometry was performed on a HP 5972 Mass Selective Detector (MSD). Ions characteristic of the internal standard (naphthalene) and target compounds were monitored in the selected ion monitoring (SIM) mode. Target compound standards were run at the start of each sample set and at regular intervals within sample sets. Target compound concentration in each sample was calculated from the peak areas ratio of target compound over the internal standard. This ratio was then converted to concentration by reference to standard curves. Masses of target compounds (bromoform, dibromoacetic acid, dibromochloromethane and bromochloroacetic acid) are expressed as mass compound per unit algal dry weight. Commercial standards used were bromoform and dibromochloromethane (SigmaAldrich), dibromoacetic acid (methyl ester) and bromochloroacetic acid (methyl ester) (Chem Service).

This quantification method was used to determine the levels of the major metabolites in both the tetrasporophyte and gametophyte of Asparagopsis armata. Comparisons were also made between field-sampled and laboratory-cultured tetrasporophytes. Laboratoryculture conditions were at $19^{\circ} \mathrm{C}$ under $20 \mu \mathrm{mol}$ photons $\mathrm{m}^{-2} \mathrm{~s}^{-1}$ with $36 \mathrm{~W}$ daylight fluorescent lighting with a 16:8 h light:dark cycle. For field samples, approximately 6 individual tetrasporophytes and 6 partial samples of the morphologically-larger gametophyte were collected at 4 times when the 2 life-history stages co-exist in the same habitat. Levels of bromoform in field samples were analysed using a 2-factor mixed model ANOVA with Life Stage $(n=2)$ as a fixed factor, and Sample Time $(\mathrm{n}=4)$ as a random factor. Levels of DBA in field samples were analysed using a 2-factor mixed model ANOVA with Life Stage $(n=2)$ as a fixed factor, and Sample Time $(\mathrm{n}=3)$ as a random factor. Comparisons between the tetrasporophyte and game- 
tophyte were made for each metabolite using 2-factor mixed model ANOVAs, with Life Stage as a fixed factor and Sample Time as a random factor. Levels of the bromoform and DBA from laboratory-cultured tetrasporophytes and field-sampled tetrasporophytes were analysed individually with 1-factor ANOVA.

Quantification of metabolite release. To determine whether metabolites were released from Asparagopsis armata, the concentration of bromoform and DBA was quantified in culture medium using the method of Cancho et al. (1999). Individuals of tetrasporophytes of A. armata ( $\mathrm{n}=9, \sim 4 \mathrm{mg}[\mathrm{DW}] \mathrm{ind}^{-1}$ ) were cultured in $25 \mathrm{ml}$ of sterile seawater in $70 \mathrm{ml}$ sealed dishes at $19^{\circ} \mathrm{C}$ under $14 \mu \mathrm{mol}$ photons $\mathrm{m}^{-2} \mathrm{~s}^{-1}$ with a 16:8 h light:dark cycle for $7 \mathrm{~d}$, after which $20 \mathrm{ml}$ of culture media was transferred to $40 \mathrm{ml}$ screw-cap vials. Three $\mathrm{ml}$ of concentrated $\mathrm{H}_{2} \mathrm{SO}_{4}, 12 \mathrm{~g}$ of anhydrous $\mathrm{Na}_{2} \mathrm{SO}_{4}, 3 \mathrm{~g}$ of $\mathrm{Cu}(\mathrm{II}) \mathrm{SO}_{4}$ and $2 \mathrm{ml}$ of methyl-tertiary-butyl ether (MTBE) (with naphthalene $50 \mu \mathrm{g} \mathrm{ml}^{-1}$ as internal standard) were added to the vials, which were then shaken for $2 \mathrm{~min}$ and left to stand for $5 \mathrm{~min}$ to allow for liquidliquid partitioning. A $1 \mathrm{ml}$ sample of the MTBE layer was transferred into $2 \mathrm{ml}$ of $\mathrm{MeOH} / \mathrm{H}_{2} \mathrm{SO}_{4}(10 \%)$ and placed in a water bath at $50^{\circ} \mathrm{C}$ for $1 \mathrm{~h}$. This mixture was cooled to $4^{\circ} \mathrm{C}$ for $10 \mathrm{~min}, 5 \mathrm{ml}$ of $\mathrm{Cu}(\mathrm{II}) \mathrm{SO}_{4}(10 \%) / \mathrm{Na}_{2} \mathrm{SO}_{4}(5 \%)$ added and subsequently shaken for $2 \mathrm{~min}$. The MTBE layer was removed and $2 \mu$ injected into the gas chromatograph. Whole thalli from each replicate container were frozen, freeze-dried and extracted in $\mathrm{MeOH}$. GC-MS analysis on the extracted medium and algae were run in SIM mode as previously described. Standards for bromoform and DBA were made in MTBE (with naphthalene at $50 \mu \mathrm{g} \mathrm{ml}^{-1}$ as internal standard).

Screening of metabolites against known microorganisms. Bromoform and DBA were tested against the same 6 strains of bacteria used in the assay of Asparagopsis armata extracts: Vibrio harveyii, V. alginolyticus, Pseudomonas aeruginosa, Staphylococcus aureus, S. epidermis and Escherichia coli. Bacteria were cultured as described previously, and both treatments added to each replicate plate as a split-plot design. Of each compound, $5 \mu \mathrm{mol}$ were stab-inoculated onto the agar plate. As bromoform is liquid at room temperature, it was applied directly to the agar plate. DBA was made up in DEE at $1 \mu \mathrm{mol} \mu \mathrm{l}^{-1}$, and $5 \mu \mathrm{l}$ applied. DEE controls $(5 \mu \mathrm{l})$ were applied adjacent to the DBA. An analysis of the size of activity zones for each bacterial strain was made using a partially-nested ANOVA (with each Plate nested within Strain) and Compound (bromoform or DBA) as fixed factor.

Penicillin-G was tested as a positive control against Escherichia coli. Penicillin-G $(5 \mu \mathrm{mol})$ was applied directly to the bacterial lawn, as above. The size of the inhibition zone was compared to $5 \mu \mathrm{mol}$ inoculates of bromoform and DBA.
Effect of bromine on Asparagopsis armata cell structure and chemistry. We investigated the importance of bromine in the formation of vesicles in Asparagopsis armata gland cells through the manipulation of bromine in the culture medium. This method uses half strength PES-enriched artificial culture medium (Provasoli 1968) with the addition of $60 \mu \mathrm{g} \mathrm{l}^{-1} \mathrm{NaIO}_{3}$. This enabled us to make culture media with and without bromide ions, bromide $(+)$ and bromide $(-)$, respectively, which has been successful in culturing Delisea pulchra (Dworjanyn et al. 1999). For bromide (+) medium, NaBr was added to give bromide ions at a concentration of $64 \mathrm{mg} \mathrm{g}^{-1}$. An equimolar amount of $\mathrm{NaCl}$ was added to bromide (-) medium to maintain salinity. Apical cuttings of the tetrasporophyte of A. armata were taken from field specimens and cultured in these media for $4 \mathrm{wk}$ at $19^{\circ} \mathrm{C}$ under $20 \mu \mathrm{mol}$ photons $\mathrm{m}^{-2} \mathrm{~s}^{-1}$ with a 16:8 h light:dark cycle.

The effects of the removal of bromine from the culture medium on algae were measured using light microscopy and GC-MS. As the major vesicle of the gland cell is highly refractive, light microscopy was used to examine the development of vesicles in algae cultured in bromide (+) and bromide (-) media. Tetrasporophytes and gametophytes grown in the 2 different media were viewed and photographed using a Leica DM LB microscope fitted with a Leica DC100 digital camera. Small clippings or whole pieces of algae were mounted (unstained) in seawater and viewed with bright field optics $(40 \times$ and $100 \times$ lenses) to examine the position of the gland cells and identify potential structures involved in surface release of metabolites. The effects of bromine on the natural product chemistry of the algae (both halogenated and non-halogenated) were examined using GC-MS (as described above).

Bacterial densities on Asparagopsis armata cultured in bromide (+) and bromide (-) media. Bromide $(-)$ plants do not produce halogenated metabolites (see 'Results'). This outcome was used to test the antibacterial activity of Asparagopsis armata by counting bacterial numbers on the surface of bromide $(+)$ and bromide (-) algae. If the brominated metabolites are active against epiphytic bacteria, then densities should be higher on the surface of those plants grown in bromide (-) media. A. armata collected for culturing was not cleansed of bacteria, as this alga grows poorly under axenic conditions (N. Paul unpubl. data). Consequently, epiphytic bacteria from the field were present in all cultures. Surface bacteria on tetrasporophytes (from clippings) and gametophytes (settled from spores) of $A$. armata grown in bromide (+) and bromide $(-)$ media for $4 \mathrm{wk}$ were stained with the green fluorescent nucleic acid stain Syto ${ }^{\circledR}$ (Molecular Probes) for $3 \mathrm{~min}$. Bacteria were viewed under a $100 \times$ lens with a Leica DM LB microscope fitted with a 100 W Hg 
fluorescence lamp and a GFP (green fluorescent protein)-specific filter. Total bacterial densities were determined for $600 \mu^{2}$ areas at apical and mature regions of tetrasporophytes and gametophytes, 100 and $700 \mu \mathrm{m}$ from the apical tip, respectively. The latter was chosen as the 'mature' region as this was close to the maximum size of the algal cells. For the gametophyte, lateral branches (determinate branches $700 \mu \mathrm{m}$ from the tip) were also measured.

In both experiments, separate individuals were used for each region, and replicate measurements $(n=3$ for gametophytes and $\mathrm{n}=6$ for tetrasporophytes) were made on different branches within an individual. Bacterial density was analysed by 3-factor mixed model ANOVA with Media (bromide [+] versus bromide [-], including a 'seawater control' as an additional treatment for the tetrasporophyte) and Region (apex versus mature, including 'lateral branch' as an additional treatment for the gametophyte) as fixed factors, and the random factor Individual $(n=3)$ nested in each Media by Region combination.

In order to control for the possible unknown effects on the epiphytic bacterial community caused by the removal of bromine, surface bacterial densities on the filamentous red alga Bostrychia moritziana (Sonder ex Kuetzing) J. Agardh, an alga with no known halogenated metabolites (as determined by GC-MS analysis of the $\mathrm{MeOH}$ extract), were measured for individuals grown with and without bromine. Bacterial densities were analysed by 3-factor mixed model ANOVA with Media (bromide [+] and bromide [-]) and Region (apex and mature) as fixed factors, and Individual $(\mathrm{n}=3$ ) nested in Media by Region. Six replicate measurements (i.e. branches) were taken for each individual in Media by Region.

Antibacterial assays using bromide (+) and bromide (-) algae. If metabolites from Asparagopsis armata are active against bacteria, then bacteria that are common on metabolite-free algae may be more susceptible to these metabolites than bacteria common on metabolite-producing algae. To test this, bacteria were sampled from bromide (+) and bromide (-) algae and assayed against bromoform and DBA. Epiphytic strains were grown with Marine broth/agar. Bacterial colonies were obtained either by streaking algae over agar or from a dilution series (after algae were vortexed in sterile seawater for $5 \mathrm{~min}$ ). Six bacterial isolates unique to bromide (+) and 6 from bromide (-) algal cultures were selected based on differences in colony colour and morphology (Bromide [+] 1-6, and, Bromide [-] 1-6). These bacteria were not characterised beyond their origin (either bromide [+] or bromide [-] algae). Isolates were added to $5 \mathrm{ml}$ of Marine Broth and shaken at $33^{\circ} \mathrm{C}$ for $24 \mathrm{~h}$. Aliquots $(150 \mu \mathrm{l})$ of culture were spread evenly over Marine Agar. Both com- pounds $(5 \mu \mathrm{mol})$ were stab-inoculated into bacterial growth plates. Three replicate plates of each bacterial isolate were inoculated with both bromoform and DBA in a split-plot design. Bromoform is liquid at room temperature and was stabbed into the surface of the agar plate. DBA was dissolved in DEE and $5 \mu \mathrm{l}$ of solution and then stabbed into the plate. A DEE control (5 $\mu \mathrm{l})$ was inoculated adjacent to DBA treatment. Plates were incubated at $30^{\circ} \mathrm{C}$ for $24 \mathrm{~h}$ at which time activity zones surrounding the inoculation stab point were calculated. Activity zones are reported as the surface area $\left(\mathrm{cm}^{2}\right)$ of growth limitation, as indicated by a front in the resulting bacterial lawn. The size of the activity zones was analysed as a split-plot, partially-nested ANOVA (with each Plate nested within Media, and Compound as fixed factor).

Culture-based assays were also used to determine the effects of Asparagopsis armata cultured in bromide (+) and bromide (-) media on a laboratory bacterial strain Chromobacterium violaceum. C. violaceum was grown with LB-10 agar. For $C$. violaceum assays, bromide (+) and bromide (-) tetrasporophytes were immersed in agar inoculated with $C$. violaceum and incubated for $24 \mathrm{~h}$ at $30^{\circ} \mathrm{C}$. Zones of activity were determined by the absence of pigment from the growth medium.

Statistical analysis. The analyses of the experimental designs outlined in each of the above sub-sections were performed using Systat 10 (SPSS). Where appropriate, transformations of the data (detailed in 'Results') were made to satisfy the ANOVA assumptions of normality and heterogeneity of variance (Quinn \& Keough 2002). Post-hoc comparisons were made using Tukey's test for multiple comparisons where required.

\section{RESULTS}

\section{Antibiotic tests of Asparagopsis armata extracts}

Both $\mathrm{MeOH}$ and DCM extracts (Fig. 1A) were active against all 6 strains of bacteria. The solvent control (DEE) had low levels of activity against all bacterial strains, and the size of this zone of activity was subtracted from the total activity zone of the extract treatments for each replicate plate. For the DCM extracts, there was no difference in efficacy between the tetrasporophyte and gametophyte (Table 1, ANOVA: $F_{1,13}=1.68, \mathrm{p}=0.217$ ). Differences in susceptibility between the different strains was also found (Fig. 1A, ANOVA: $\left.F_{5,13}=3.71, \mathrm{p}=0.026\right)$; Escherichia coli and Pseudomonas aeruginosa were the most susceptible to the DCM extract, while Vibrio spp. were the least susceptible (Fig. 1A). Whole pieces of the tetrasporophyte of Asparagopsis armata inhibited growth of Chromobacterium violaceum (Fig. 1B). 

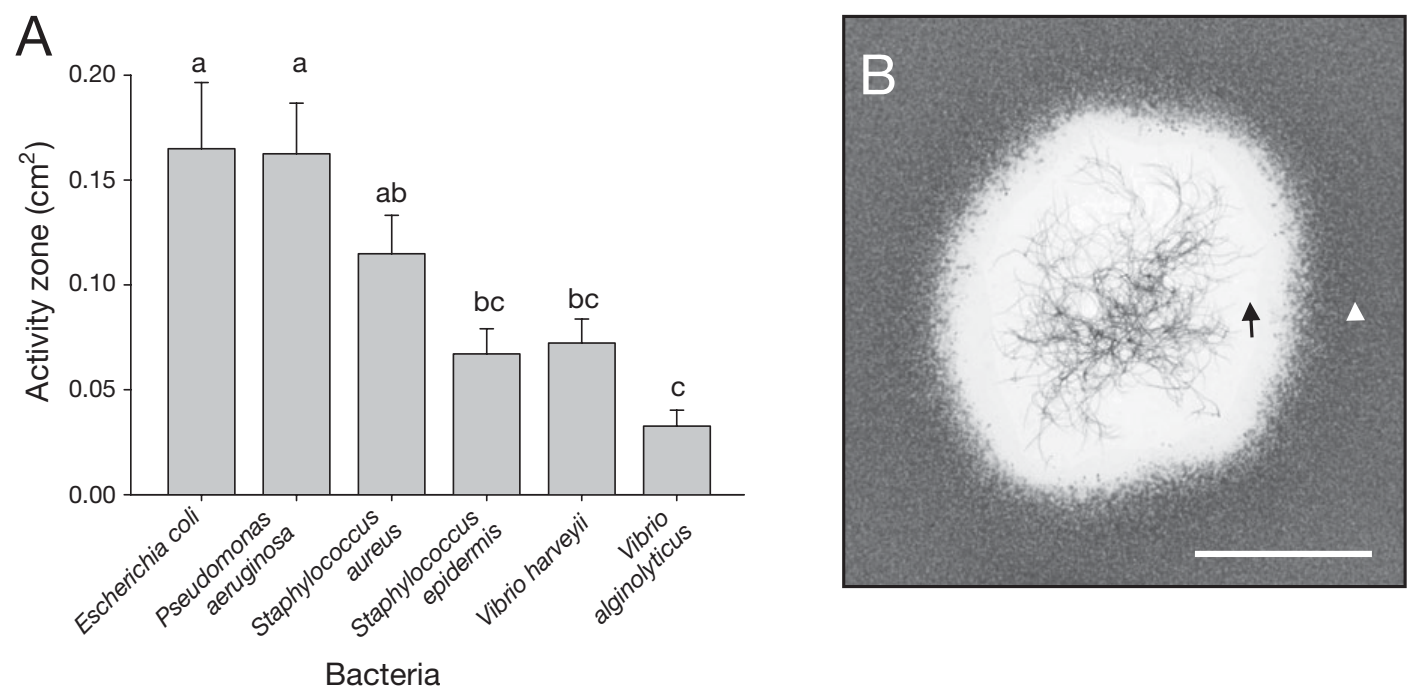

Fig. 1. (A) Areas of antibacterial activity (mean $+\mathrm{SE}, \mathrm{n}=3$ ) of the dichloromethane extracts of tetrasporophytes and gametophytes (combined) against known bacteria. Bacteria sharing the same letter do not differ at $\alpha=0.05$ (Tukey's multiple comparison). (B) Chromobacterium violaceum (arrow head) is growth-inhibited (arrow) around the filamentous tetrasporophyte of Asparagopsis armata. Scale bar $=5 \mathrm{~mm}$

\section{Natural product chemistry of Asparagopsis armata}

Mass spectral fragmentation patterns of the major peaks from the methanol extracts of Asparagopsis armata were used in the structural assignment of bromoform, DBA (methyl ester), dibromochloromethane, bromochloroacetic acid (methyl ester) and dibromoacrylic acid (methyl ester). These structures were confirmed using commercial standards, except for dibromoacrylic acid (methyl ester). The mass spectrum of dibromoacrylic acid (methyl ester) matched the spectrum previously described for methyl 3, 3 dibromoacrylate (Woolard et al. 1979).

Table 1. Asparagopsis armata. Results of 3-factor partially-nested ANOVAs testing the antibacterial effect of the DCM extracts (Life Stage: tetrasporophyte vs. gametophyte) and pure compounds (Compound: bromoform vs. dibromoacetic acid) on 6 known bacterial strains. Significant values at $p<0.05$ are in bold

\begin{tabular}{|lrccc|}
\hline Source & df & MS & $F$ & $p$ \\
\hline DCM extracts & & & & \\
Strain & 5 & 0.019 & 3.71 & $\mathbf{0 . 0 2 6}$ \\
Plate (Strain) & 13 & 0.005 & 3.74 & $\mathbf{0 . 0 1 2}$ \\
Life Stage & 1 & 0.002 & 1.68 & 0.217 \\
Strain $\times$ Life Stage & 5 & 0.001 & 0.79 & 0.576 \\
Error & 13 & 0.001 & & \\
Pure compounds & & & & \\
Strain & 5 & 0.201 & 7.58 & $\mathbf{0 . 0 0 2}$ \\
Plate (Strain) & 13 & 0.026 & 0.80 & 0.656 \\
Compound & 1 & 8.220 & 247.28 & $<\mathbf{0 . 0 0 1}$ \\
Strain $\times$ Compound & 5 & 0.220 & 6.62 & $\mathbf{0 . 0 0 3}$ \\
Error & 13 & 0.059 & & \\
\hline
\end{tabular}

Bromoform was the dominant metabolite in Asparagopsis armata, with mean levels across sampling times of $1.45 \% \mathrm{DW}( \pm 0.12 \mathrm{SE})$ for the tetrasporophyte (ranging from 0.58 to $3.11 \% \mathrm{DW})$ and $1.67 \% \mathrm{DW}( \pm 0.16 \mathrm{SE})$ for the gametophyte (ranging from 0.66 to $4.35 \% \mathrm{DW}$ ). The amount of bromoform varied depending on both the life stage and sampling time (Table 2, ANOVA: $\left.F_{3,50}=7.15, \mathrm{p}<0.001\right)$. Dibromochloromethane was present in the tetrasporophyte (mean of $0.02 \% \mathrm{DW}$ $[ \pm 0.002 \mathrm{SE}]$ ) and the gametophyte (mean of $0.03 \% \mathrm{DW}$ $[ \pm 0.003 \mathrm{SE}])$.

The amount of the methyl esters of the haloacetic acids (DBA and bromochloroacetic acid) were converted to weights (molar equivalent) of the corre-

Table 2. Asparagopsis armata. Results of 2-factor mixed-model ANOVAs testing the effect of Life Stage (tetrasporophyte vs. gametophyte) and Sample Time on the internal levels of bromoform and dibromoacetic acid (DBA). All data were log $(x+1)$ transformed. Significant values at $p<0.05$ are in bold

\begin{tabular}{|lrrrr|}
\hline Source & df & MS & \multicolumn{1}{c|}{$F$} & $\mathrm{p}$ \\
\hline Bromoform & & & & \\
Life Stage & 1 & 0.002 & 0.01 & 0.926 \\
Sample Time & 3 & 0.578 & 17.04 & $<\mathbf{0 . 0 0 1}$ \\
Life Stage $\times$ Sample Time & 3 & 0.243 & 7.15 & $<\mathbf{0 . 0 0 1}$ \\
Error & 50 & 0.034 & & \\
DBA & & & & \\
Life Stage & 1 & 0.836 & 67.46 & $\mathbf{0 . 0 1 5}$ \\
Sample Time & 2 & 0.059 & 0.73 & 0.489 \\
Life Stage $\times$ Sample Time & 2 & 0.012 & 0.15 & 0.858 \\
Error & 34 & 0.081 & & \\
\hline
\end{tabular}


sponding acids. Levels of DBA were higher in the tetrasporophyte than in the gametophyte (Fig. 2, and Table 2, ANOVA: $\left.F_{1,34}=67.46, \mathrm{p}=0.015\right)$, and overall levels varied between 0.12 to $2.6 \%$ DW (mean $0.74 \%$ DW [ $\pm 0.16 \mathrm{SE}])$ for the tetrasporophyte, and 0.02 to $1.1 \%$ DW for the gametophyte (mean $0.25 \%$ DW [ $\pm 0.06 \mathrm{SE}])$. Bromochloroacetic acid was found in the tetrasporophyte (mean of $0.14 \%$ DW $[ \pm 0.02 \mathrm{SE}]$ ) and the gametophyte (mean of $0.08 \%$ DW [ $\pm 0.01 \mathrm{SE}]$ ) (Fig. 2). Dibromoacrylic acid (methyl ester) was not quantified due to the absence of a standard. Amounts and ratios of the major halogenated metabolites were the same for field-collected and laboratory-cultured tetrasporophytes (Bromoform: $F_{3,22}=2.79$, $\mathrm{p}=0.065$; DBA: $\left.F_{3,22}=0.43, \mathrm{p}=0.716\right)$.

\section{Release of major metabolites}

The detection of bromoform and the methyl ester of DBA in culture medium using the MTBE extraction demonstrate that these same compounds are also released from the tetrasporophyte. The levels of these compounds in the medium indicated a release rate of $1110 \mathrm{ng} g(\mathrm{DW})^{-1} \mathrm{~h}^{-1}( \pm 393 \mathrm{SE})$ for bromoform, and $539 \mathrm{ng} g(\mathrm{DW})^{-1} \mathrm{~h}^{-1}( \pm 166 \mathrm{SE})$ for DBA. Background levels of bromoform (but not DBA) were detected in seawater controls and the mean value of this subtracted from each bromoform measurement. The average internal levels in the test algae were $1.57 \%$ DW

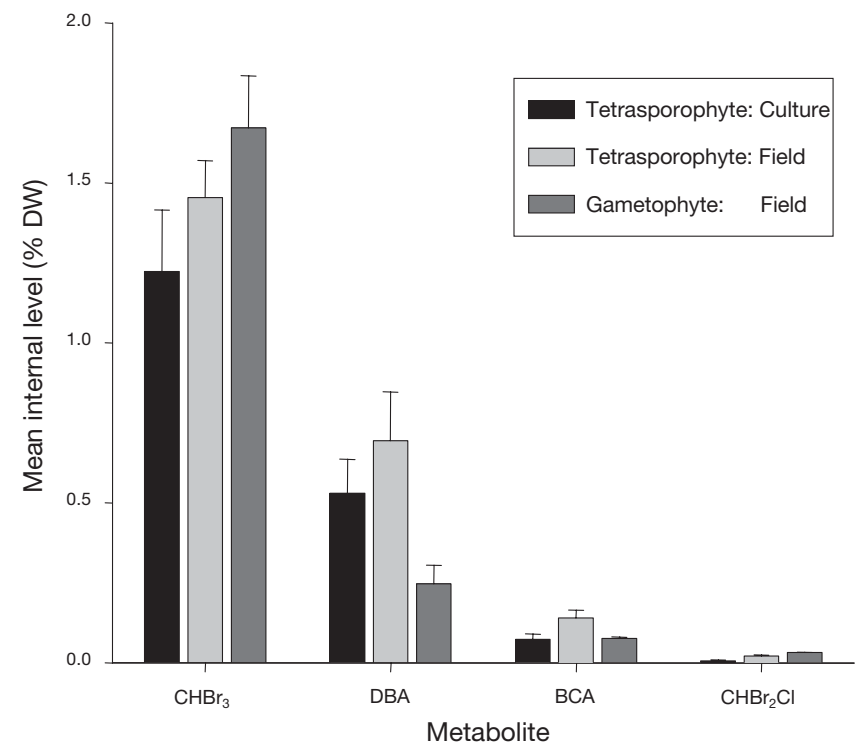

Fig. 2. Asparagopsis armata. Internal level of the major halogenated metabolites (mean $+\mathrm{SE}, \mathrm{n}=10$ to 20 for field, $\mathrm{n}=6$ for culture) in field-sampled tetrasporophytes and gametophytes, and laboratory-cultured tetrasporophytes of $A$. armata $\left(\mathrm{CHBr}_{3}\right.$ : bromoform; DBA: dibromoacetic acid; BCA: bromochloroacetic acid; $\mathrm{CHBr}_{2} \mathrm{Cl}$ : dibromochloromethane)
$( \pm 0.19 \mathrm{SE})$ for bromoform, and $0.79 \% \mathrm{DW}( \pm 0.05 \mathrm{SE})$ for DBA. The total amounts of each compound released over a $1 \mathrm{wk}$ period are small relative to the amounts retained in the tissue (released: internal, bromoform = 1:77, and DBA = 1:83; assuming no new growth of the alga in this time). The 3 other major halogenated metabolites in Asparagopsis armata (dibromochloromethane, bromochloroacetic acid and dibromoacrylic acid) were also detected in some of the culture media replicates, but were not quantitatively analysed.

The data for the release rates of bromoform and DBA were highly variable. There were no significant correlations between the internal concentration of either metabolite and the amount released; bromoform (Pearson coefficient $=0.234, \mathrm{p}=0.545$ ) and DBA (Pearson coefficient $=0.314, p=0.412$ ). There was also no correlation between the amounts of bromoform and DBA released (Pearson coefficient $=0.370, p=0.328$ ), despite a strong positive relationship between the internal levels of these compounds (Pearson coefficient $=0.955, \mathrm{p}<0.001)$. While the individual release rates were variable, the ratio of the average level of release of the metabolites (bromoform: DBA $=1.93$ ) is close to that of the ratio of the averages of the internal level in the algae (bromoform: DBA = 1.88).

\section{Antibiotic testing of major metabolites}

Both bromoform and dibromoacetic acid (5 4 mol of each) showed activity against the 6 bacterial strains assayed. Different strains were more susceptible to one compound than the other, as shown by a significant interaction between strain and compound (Table 1, ANOVA: $F_{1,13}=6.62, \mathrm{p}=0.003$ ). The size of activity zones surrounding the inoculation point was much larger for DBA than for bromoform against all bacteria (Fig. 3, and Table 1, ANOVA: $F_{1,13}=247.28$, p < 0.001), although the potential differences in solubility of each compound in agar limits direct comparison.

The mean size of the Escherichia coli inhibition zone surrounding Penicillin-G was $6.17 \mathrm{~cm}^{2}$ ( $\left.\pm 0.25 \mathrm{SE}\right)$, which was a larger effect than either bromoform $\left(0.019 \mathrm{~cm}^{2}\right)$ or DBA $\left(1.05 \mathrm{~cm}^{2}\right)$, though direct comparisons are constrained by differences in solubility.

\section{Effect of bromine on cell structure and chemistry}

Gland cells of Asparagopsis armata occupy space within other cells of the alga (Fig. 4A (arrow heads) \& Fig. 5A-E). The removal of bromine from the culture medium resulted in the loss of refractile vesicles in both the tetrasporophyte (Fig. 4B) and gametophyte (data not shown). The loss of vesicles corresponded to 


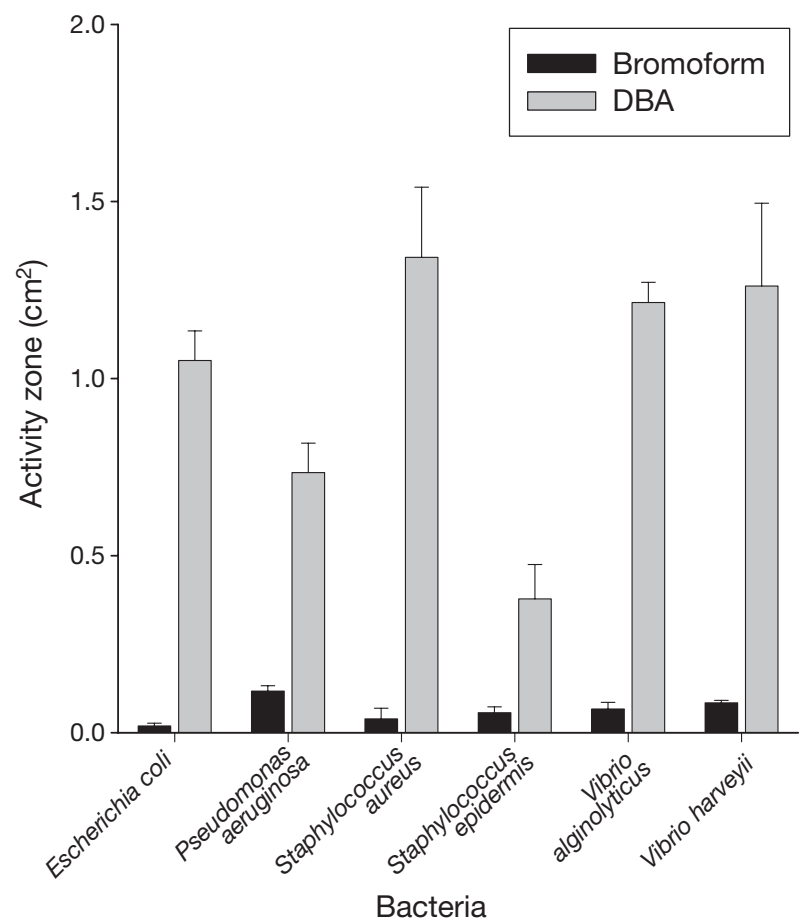

Fig. 3. Asparagopsis armata. Areas of antibacterial activity $($ mean $+\mathrm{SE}, \mathrm{n}=3)$ of pure compounds (bromoform and dibromoacetic acid) from $A$. armata against different bacterial strains. There was a significant interaction between bacteria and compound (see Table 1 for ANOVA results) the absence of halogenated metabolites (Fig. 4D). Algae cultured with bromine continued to produce the major metabolites at comparable levels to seawater cultures (bromide [+]; e.g. bromoform: 0.44 DW $[ \pm 0.14 \mathrm{SE}]$; DBA: $0.08 \%[ \pm 0.06 \mathrm{SE}])$, although these values were in the lower range of production compared to both seawater cultures and environmental samples. Removal of bromide from the medium did not interfere with the production of non-halogenated compounds (Compounds 1-5, Fig. 4B). Growth of algae in artificial seawater without bromine appears to have minimal effect on cells other than the loss of the vesicle from gland cells.

\section{Gland cells and related structures}

The gland cell is located inside the parent cell (Fig. 5). Thus, an additional mechanism is required to transfer material from the gland cell to the surface for metabolites to be released. Such a link is maintained via a structure which connects the gland cell to the opposite (outer) wall of the parent (pericentral) cell in tetrasporophytes (Fig. 5A) and the parent (epidermal) cell of the gametophyte (Fig. 5B). These structures are extremely distinct in the lateral branches of the gametophyte, and material may be associated with them

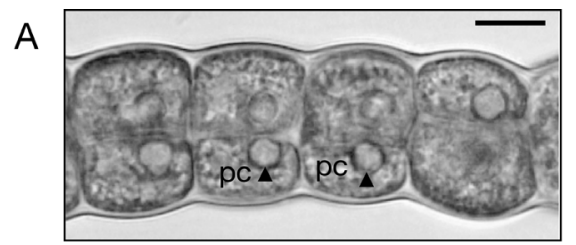

$\mathrm{B}$
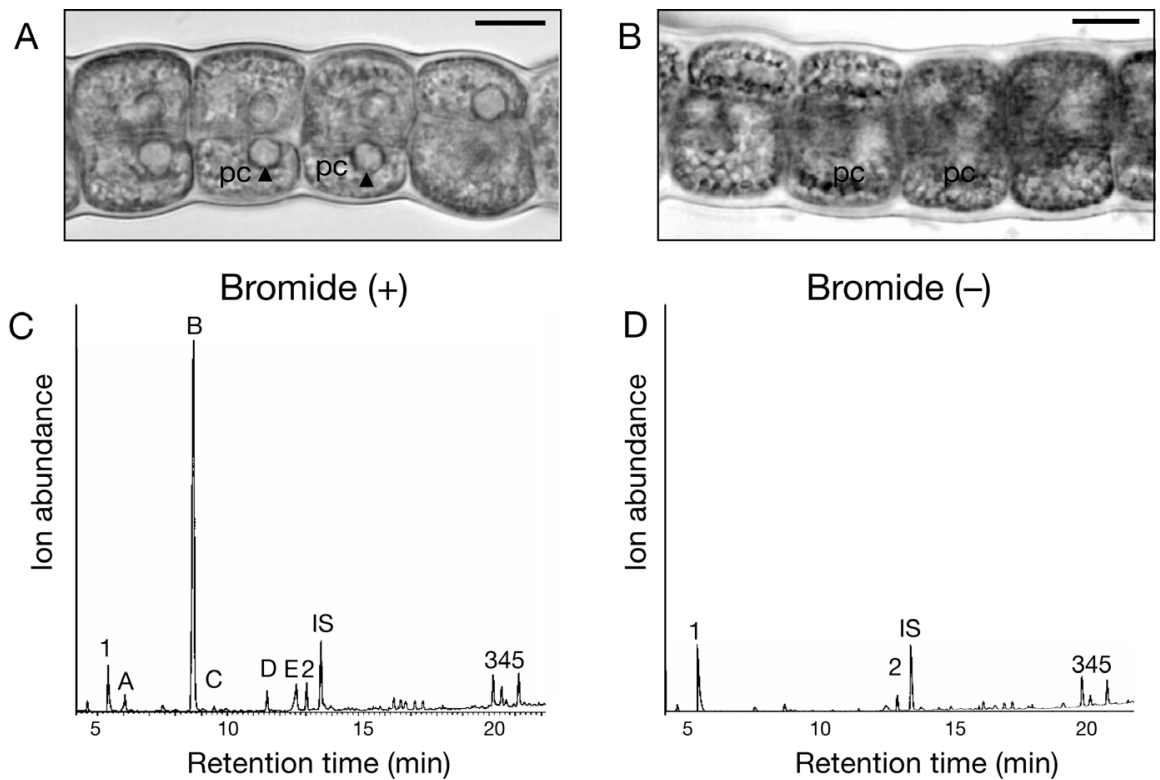

Fig. 4. Asparagopsis armata. Effects of bromine manipulation on the $(\mathrm{A}, \mathrm{B})$ morphology and $(\mathrm{C}, \mathrm{D})$ chemistry of the tetrasporophyte of $A$. armata. (A) Vesicles (arrow heads) are prominent in the gland cells of bromide (+) algae, which are located inside the pericentral cell (pc) as shown in this section of filament. (B) These vesicles are no longer formed in algae grown without bromide (scale bars $=20 \mu \mathrm{m})$. (C) Gas chromatograph of the $\mathrm{MeOH}$ extract of the tetrasporophyte of A. armata showing major halogenated peaks (A: dibromochloromethane; B: bromoform; C: bromochloroacetic acid [methyl ester]; D: dibromoacetic acid [methyl ester]; E: 3,3 dibromoacrylic acid [methyl ester]; IS: internal standard [naphthalene]). (D) Gas chromatograph showing that brominated metabolites (A-E) are no longer present in bromide (-) algae. Peaks 1-5 represent non-halogenated compounds and these are found in both bromide $(+)$ and bromide $(-)$ algae $(C, D)$ 


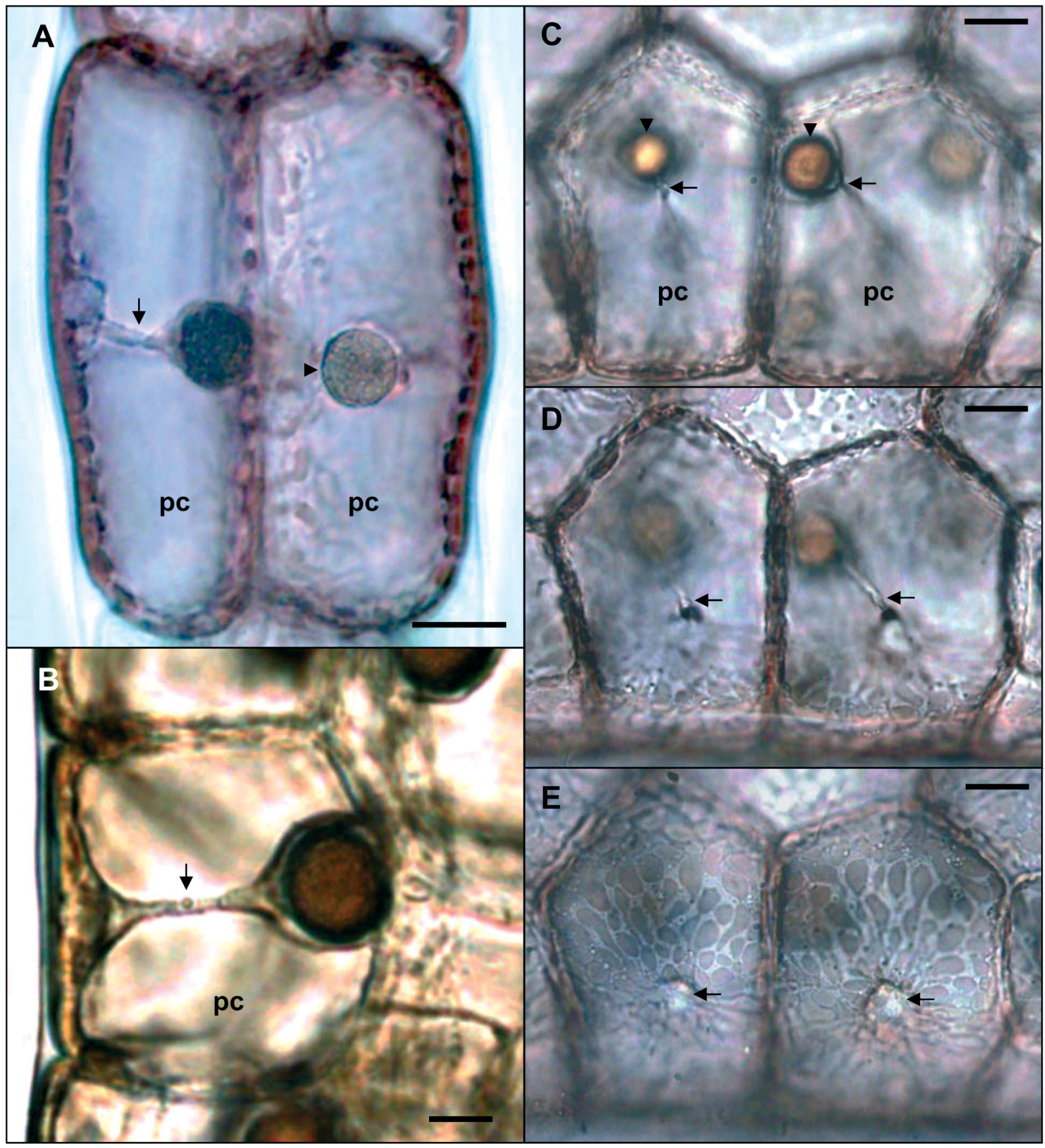

Fig. 5. Asparagopsis armata. Light micrographs of (A) the tetrasporophyte and (B-E) gametophyte of A. armata. (A) Gland cells (arrow) within pericentral (parent) cells (pc) of the tetrasporophyte and connective structure (arrow head). (B) Lateral branch of the gametophyte with a gland cell within the parent cell (pc) showing a structure connecting the gland cell to the outer cell wall. Material may be seen on this structure (B, arrow). (C-E) Images of these structures (arrows) originating at 2 gland cells $(\mathrm{C}$, arrow heads) in the parent (epidermal) cells (pc) of the gametophyte as seen moving up through 2 focal planes towards the algal surface. The structure appears tubular in nature (D, arrows). Scale bars: $(A, B)=10 \mu m_{i}(C-E)=20 \mu m$ 
(Fig. 5B, arrow). In the sequence of images rising through focal planes from 2 gland cells (arrow heads) in the gametophyte (Fig. 5C-E), the structure appears to be tube-like in nature.

\section{Epiphytic bacterial densities on bromide (+) and bromide (-) algae}

Densities of bacteria were significantly higher on both tetrasporophytes and gametophytes of Asparagopsis armata which lacked brominated secondary metabolites (bromide [-]) than on algae that produced metabolites (bromide [+]) (Fig. 6A,B \& Table 3, tetrasporophyte: $F_{2,12}=39.14, \mathrm{p}<0.001$; gametophyte: $\left.F_{1,12}=33.19, \mathrm{p}<0.001\right)$. For the tetrasporophyte, bromide (-) algae had significantly higher densities than both other treatments (Fig. 6A, Tukey's test: $(\alpha=0.05)$ bromide $(-)>$ bromide $(+)=$ seawater $)$. This represents a 14-fold (apex) to 20-fold (mature) difference in mean bacterial densities ( $\mathrm{Br}[-]: \mathrm{Br}[+])$. For the gametophyte of $A$. armata, the mean difference ranged from $3: 2$ to 3:1 between the 3 regions (apical cells, mature cells and lateral branch cells). There was no difference in bacterial density on the control alga Bostrychia moritziana in bromide (+) and bromide (-) media (Fig. 6C \& Table 4, $F_{1,8}=0.51, \mathrm{p}=0.496$ ).

For both the tetrasporophyte of Asparagopsis armata and control alga Bostrychia moritziana, bacterial densities were higher $\left(F_{1,12}=11.59, \mathrm{p}=0.005 ; F_{1,8}=30.28\right.$, $\mathrm{p}<0.001$, respectively) on older (mature) parts of the algal filament than on younger (apex) parts (Fig. 6, Tables 4 \& 5). There was no difference in bacterial densities between the regions of the gametophyte of A. armata (Table 3). For both tetrasporophytes and gametophytes of $A$. armata, there was no effect of 'Individual' (Table 3), indicating variance within each Media by Region group was minimal.

\section{Antibacterial assays with bromide (+) and bromide (-) algae}

Bacterial isolates from the surface of algae that no longer produced halogenated metabolites (bromide [-]) were more susceptible to bromoform and DBA than bacteria isolated from metabolite-producing algae (Fig. 7A,B \& Table 5, $F_{1,34}=12.48, \mathrm{p}=0.001$ ). DBA was active against all 12 strains assayed. Bromoform was active against 7 of the 12 strains. Of the 5 strains that were not affected by bromoform, 4 were isolates from bromide (+)-cultured algae. There was a highly significant effect of compound $\left(F_{1,34}=374.67\right.$, $\mathrm{p}<0.001)$; however, direct comparisons are constrained by the potential difference in solubility in the
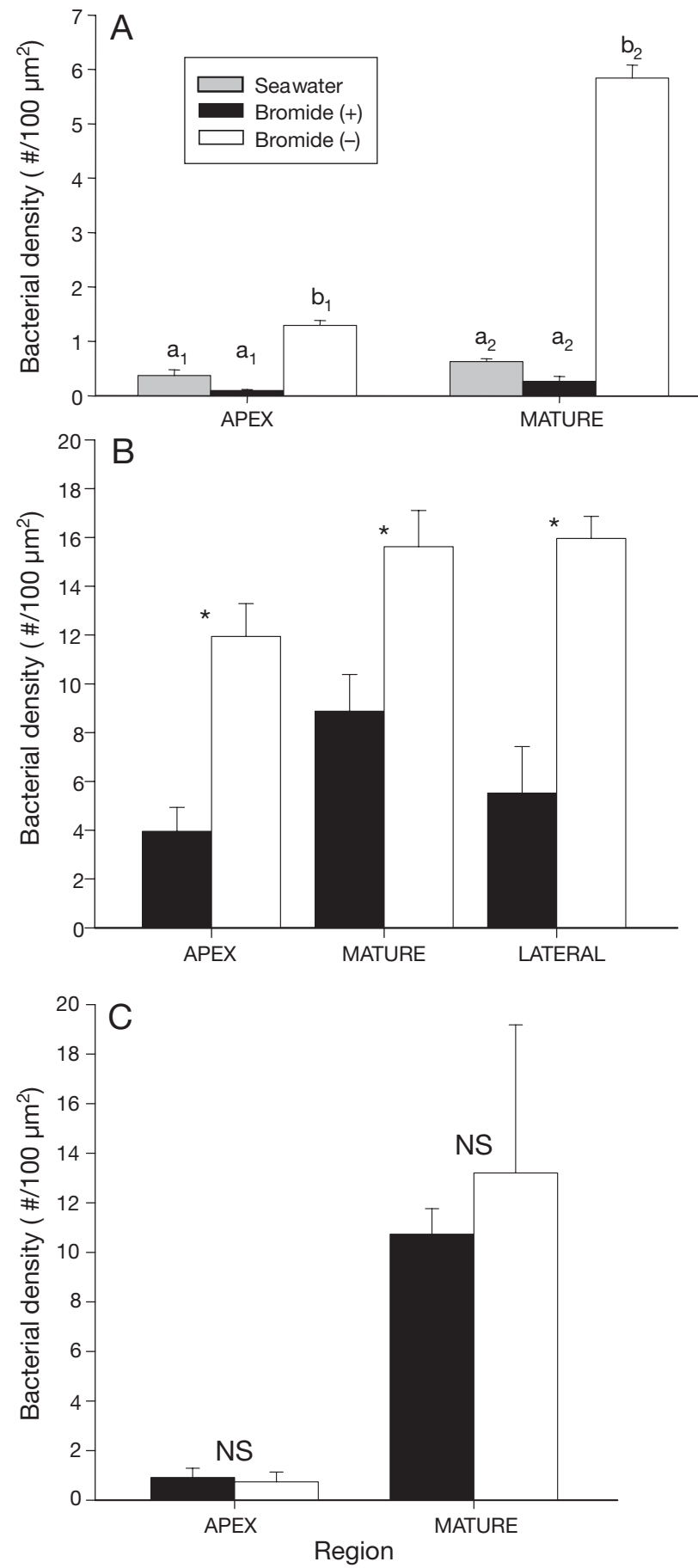

Fig. 6. Asparagopsis armata. Mean surface density of bacteria (+SE) on (A) the tetrasporophyte and (B) gametophyte of A. armata, and (C) the control alga Bostrychia moritziana, grown in bromide (+) and bromide (-) media (tetrasporophyte of $A$. armata has Seawater as a third media treatment). (A) Bars sharing the same letter in each region are not significantly different (Tukey's multiple comparison). (B,C) Significant $(*)$ or non-significant (NS) differences between bromide $(+)$ and bromide $(-)$ bacterial densities are displayed for each region. Standard errors (SE) were calculated from the averages of individuals within each subgroup (tetrasporophyte $A$. armata: $\mathrm{n}=6$; gametophyte of $A$. armata, $B$. moritziana: $\mathrm{n}=3$ ) 
Table 3. Asparagopsis armata. Results of 3-factor mixed-model ANOVA testing the effect of Media (Br[+] vs. Br[-]) and Region (Apex vs. Mature) on bacterial densities on the surface of the tetrasporophyte and gametophyte of $A$. armata. All data were $\log (x+1)$-transformed. Significant values at $\mathrm{p}<0.05$ are in bold. Tukey's multiple comparisons were used for post-hoc analyses. Tetrasporophyte (Media), Sea $=\operatorname{Br}(+)<\operatorname{Br}(-)$

\begin{tabular}{|lrrrr|}
\hline Source & df & MS & $F$ & $p$ \\
\hline Tetrasporophyte & & & & \\
Media & 2 & 10.09 & 39.14 & $<\mathbf{0 . 0 0 1}$ \\
Region & 1 & 2.98 & 11.59 & $\mathbf{0 . 0 0 5}$ \\
Media $\times$ Region & 2 & 0.87 & 3.38 & 0.069 \\
Individual & 12 & 0.26 & 0.26 & 0.259 \\
(Media $\times$ Region) & & & & \\
Error & 90 & 0.21 & & \\
Gametophyte & & & & \\
Media & 1 & 15.90 & 33.19 & $<\mathbf{0 . 0 0 1}$ \\
Region & 2 & 1.05 & 2.18 & 0.155 \\
Media $\times$ Region & 2 & 0.30 & 0.62 & 0.552 \\
Individual & 12 & 0.48 & 1.54 & 0.153 \\
(Media $\times$ Region) & & & & \\
Error & 36 & 0.31 & & \\
\hline
\end{tabular}

Table 4. Bostrychia moritziana. Results of 3-factor mixed model ANOVA testing the effect of Media (Br[+] vs. Br[-]) and Region (Apex vs. Mature) on the bacterial densities on the surface of $B$. moritziana. Data were $\log (x+1)$-transformed. Significant values at $\mathrm{p}<0.05$ are in bold

\begin{tabular}{|lrrcc|}
\hline Source & df & MS & $F$ & $\mathrm{p}$ \\
\hline Media & 1 & 0.98 & 0.51 & 0.496 \\
Region & 1 & 46.37 & 25.95 & $\mathbf{0 . 0 0 1}$ \\
Media $\times$ Region & 1 & 0.01 & 0.006 & 0.941 \\
Individual (Media $\times$ Region) & 8 & 1.79 & 4.05 & $\mathbf{0 . 0 0 1}$ \\
Error & 61 & 0.44 & & \\
\hline
\end{tabular}

agar. DEE controls had a negligible effect on bacterial growth. There appeared to be some variation in the susceptibility of individual isolates to the different compounds (Fig. 7A,B); however, this was not formally analysed.

Direct tests of algae with and without halogenated secondary metabolites (bromide [+] and bromide [-], respectively) were consistent with an antibacterial function for the halogenated metabolites of Asparagopsis armata. When bromide $(+)$ and bromide $(-)$ algae were infused in cultures of Chromobacterium violaceum, bromide (+) algae produced highly visible areas of antibacterial activity (Fig. 7C,D).

\section{DISCUSSION}

Asparagopsis armata produces compounds that inhibit a range of bacteria in standard antibacterial plate assays. These compounds are stored in and released
Table 5. Asparagopsis armata. Results for 3-factor partiallynested ANOVA testing the antibacterial effect of Compound (bromoform vs. dibromoacetic acid) against bacteria isolated from $A$. armata grown in different Media $(\operatorname{Br}[+]$ vs. $\operatorname{Br}[-])$. Data were $\log (x+1)$-transformed. Significant values at $\mathrm{p}<0.05$ are in bold

\begin{tabular}{|lrrrr|}
\hline Source & df & MS & \multicolumn{1}{c|}{$F$} & $\mathrm{p}$ \\
\hline Media & 1 & 0.256 & 12.48 & $\mathbf{0 . 0 0 1}$ \\
Dish (Media) & 34 & 0.021 & 0.64 & 0.904 \\
Compound & 1 & 12.086 & 374.67 & $<\mathbf{0 . 0 0 1}$ \\
Media $\times$ Compound & 1 & 0.044 & 1.35 & 0.253 \\
Error & 34 & 0.032 & & \\
\hline
\end{tabular}

from specialised gland cells. The gland cell is internal to the parent cell, but maintains a physical connection with the outer cell wall. This connection appears to be a means for the release of metabolites to the algal surface. Support for this assertion is the observation that the major halogenated metabolites quantified in A. armata were also detected in the surrounding culture medium. An ecological role for the natural products of $A$. armata as surface-active antimicrobial agents was demonstrated by manipulating metabolite production in the alga by omitting bromide from the medium. Epiphytic bacterial densities were significantly lower on algae that produced halogenated secondary metabolites, and bacteria isolated from the surface of these algae were more tolerant to the major compounds than bacteria from metabolite-free algae. Combined with traditional assays of natural products against bacteria, including those isolated from the algal surface, our results demonstrate that the metabolites from $A$. armata could be important in limiting growth of bacteria on the surface of this alga.

Traditionally, marine secondary metabolites have primarily been seen as defensive compounds against consumers (Hay et al. 1987, Hay \& Fenical 1988). However, recent reviews have highlighted important roles for secondary metabolites as inhibitors of surface colonisation (Potin et al. 2002, Steinberg \& de Nys 2002). More specifically, algal natural products can mediate interactions with surface microbes (Maximilien et al. 1998), which may include specific pathogens (Weinberger \& Friedlander 2000, Bouarab et al. 2001, Kubanek et al. 2003). Prior to these recent tests, antimicrobial activity of marine algae had generally been determined using terrestrial microbes, principally those bacteria of interest to humans (Sieburth \& Conover 1965, Hornsey \& Hide 1974, Al-Ogily \& Knight-Jones 1977, McConnell \& Fenical 1979). We have demonstrated that extracts of Asparagopsis armata are active in laboratory tests against Escherichia coli, Staphylococcus spp., Pseudomonas aeruginosa and 2 marine Vibrio spp. Previous investigations of $A$. armata using 

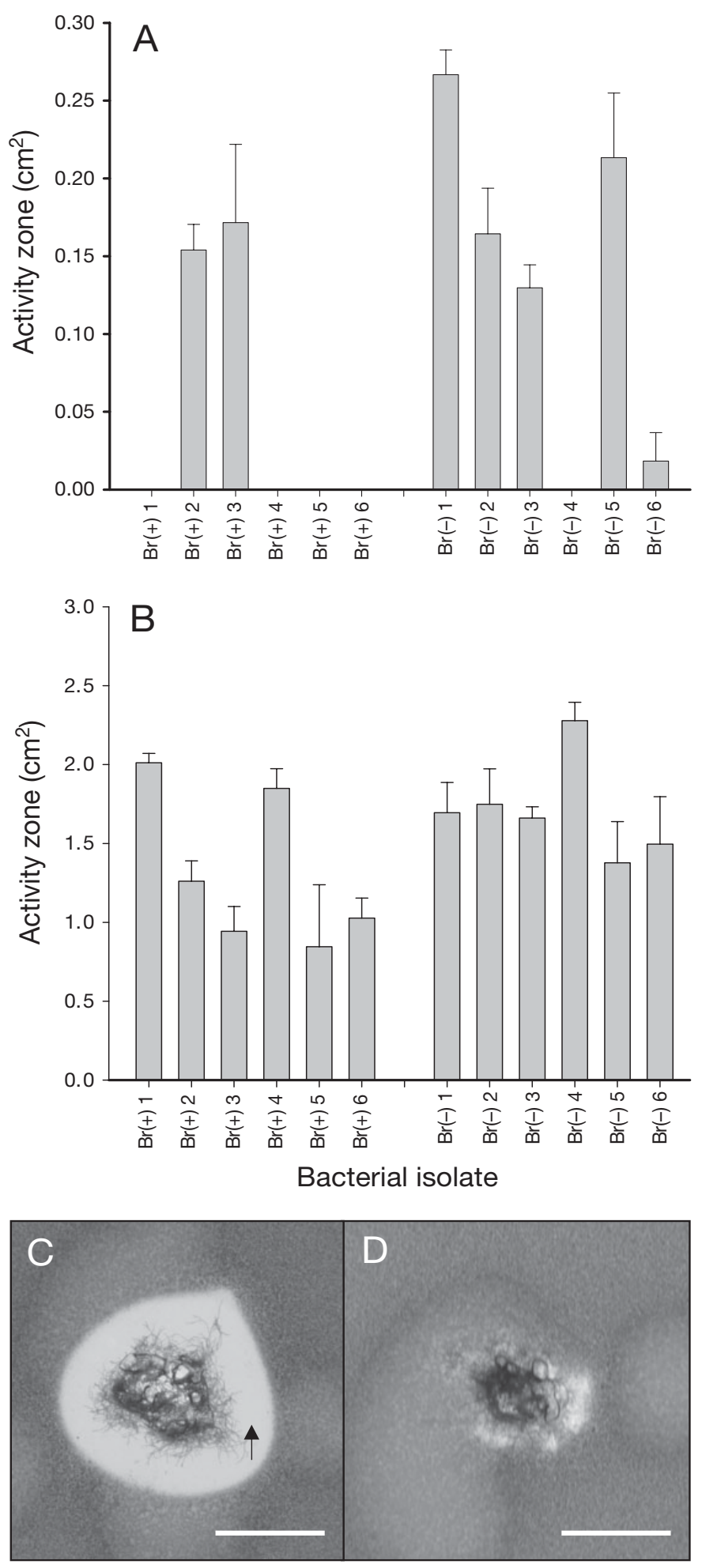

Fig. 7. $(A, B)$ Areas of antibacterial activity (mean $+\mathrm{SE}, \mathrm{n}=3$ ) of (A) bromoform and (B) dibromoacetic acid against bacterial isolates from the surface of algae with $(\mathrm{Br}[+])$ and without $(\mathrm{Br}[-])$ halogenated metabolites. (C,D) Chromobacterium violaceum assays with bacterial inhibition zone (arrow) around bromide (+) algae (C), and the corresponding assay with bromide (-) algae (D). Scale bars $=5 \mathrm{~mm}$ whole pieces (Hornsey \& Hide 1974) and isolated compounds (McConnell \& Fenical 1979) also found that the natural products from this alga can inhibit bacterial growth.

In the present study, the major natural products in Asparagopsis armata were small halocarbons (e.g. bromoform) and short-chained haloacids (e.g. DBA). No iodinated acids were detected, despite being the major acid products of Asparagopsis taxiformis (Woolard et al. 1979). Haloacetones and halobutanones, previously described for A. armata (McConnell \& Fenical 1977), were not found. The total levels of the 4 major halogenated metabolites ranged between 2 and $6 \%$ of algal DW. To date, the major metabolites had not been quantified in the genus Asparagopsis, and this range represents a high level of compounds compared to another member of the Bonnemaisoniaceae (Delisea pulchra has 0.2 to $2 \%$ DW; de Nys et al. 1996). Levels of the major metabolite (bromoform) varied with sample time and life-history stage of $A$. armata (filamentous tetrasporophyte or plumose gametophyte). The levels of DBA, the second most abundant metabolite, were consistently higher in the tetrasporophyte than in the gametophyte, with little temporal variation. Importantly, the levels of the major metabolites in the tetrasporophyte of $A$. armata in seawater culture were consistent with field-sampled tetrasporophytes. This supports the use of laboratory manipulations of $A$. armata to demonstrate the release of metabolites from the alga into the surrounding media and to test their ecological roles.

A key aspect to studies of the function of algal metabolites is the localisation of active metabolites in the alga (de Nys et al. 1998, Dworjanyn et al. 1999). Such active metabolites can be autotoxic, and the producing organism will generally require some morphological specialisation for their storage (McKey 1979). The specialised gland cells of Asparagopsis armata are completely enveloped by their parent cells. While the gland cell is not part of the epidermal layer, cells presumably release their contents through mechanical contact with the outer region of the parent cell (Fig. 5). The structure linking the gland cell and its parent cell has not previously been characterised. Transmission electron microscopy of the gland cells and associated structures in A. armata has provided further insight into the ultrastructure of the major storage vesicle and the nature of the gland cell (Paul et al. in press). In other algae, specialised cells are predominantly found in the epidermal cell layer (Young \& West 1979, Dworjanyn et al. 1999). If an alga is to release bioactive metabolites to the exterior, these specialised cells should be proximal to the algal surface. This is the case for A. armata, as a single cell wall separates the gland cell from the exterior. 
A gland cell, as the name implies, is generally secretory, although this is not always the case (Young 1979). Other types of storage structures are exclusively subcellular, e.g. the refractile inclusions (corp en cerise) of the genus Laurencia (Young et al. 1980). These internally packaged compounds cannot function in surfacemediated roles (de Nys et al. 1998), but can play a role in feeding deterrence (Hay et al. 1987). It appears that some types of inclusions can function in multiple roles. For example, brown algal physodes - structures containing phenolics typically regarded as key defensive metabolites - also have important roles in cell wall formation (Schoenwaelder 2002). These are all examples of how structure can determine function. Clearly, sufficient ultrastructural evidence (Young 1978) or the harvest, and if possible, quantification, of metabolites from the plant surface (Schmitt et al. 1995, de Nys et al. 1998), is crucial to attributing surface-mediated roles to extracted natural products.

The release of bromoform and DBA from Asparagopsis armata represents a mechanism for the interaction of these compounds with surface microbes. Many algae are known to release small halogenated compounds (Nightingale et al. 1995, Marshall et al. 1999), although it is not usually known how the compounds are released or if they are active against microbes. Similar to Marshall et al. (1999), we demonstrated release of bromoform from the tetrasporophyte of A. armata. Our measured rate of release for bromoform (1110 ng g $[\mathrm{DW}]^{-1} \mathrm{~h}^{-1}$ ) is comparable to previous reports using purge-and-trap techniques (32 to $1650 \mathrm{ng}$ $\mathrm{g}[\mathrm{DW}]^{-1} \mathrm{~h}^{-1}$; Marshall et al. 1999 ). This is a higher rate of release than most other algae (Nightingale et al. 1995). Analysis of the culture medium through liquidliquid partition, rather than through purging, esterified the haloacids, and demonstrated that the other major product (DBA) is also released (539 $\mathrm{ng}$ g $[\mathrm{DW}]^{-1} \mathrm{~h}^{-1}$ ). Release of haloacids from an alga has not previously been reported. The release rates of both bromoform and DBA were not correlated with the metabolite levels inside the algae. There was also no correlation between the rates of release of the 2 compounds, despite a strong positive correlation in the internal levels of these compounds. While there was no significant relationship between the external and internal amounts of the metabolites, the data were highly variable.

Brominated metabolites are common in red algae (Fenical 1975). However, bromide is not recognised as an essential ion for either algal growth (Fries 1966) or reproduction (McLachlan 1977). Wolk (1968) demonstrated that Asparagopsis armata grown in the absence of bromide ions no longer formed the major vesicle in gland cells, and that morphological effects aside from this were negligible. In this study, GC-MS analysis also indicated qualitative similarities of non-halogenated metabolites in bromide (+)- and bromide (-)-cultured algae. The ability to manipulate the presence of halogenated metabolites in Bonnemaisoniaceae provides a unique experimental system for testing the ecological roles of algal metabolites.

Correlations between bacterial densities on living surfaces and levels of metabolites (Sieburth \& Conover 1965, Wahl et al. 1994, Maximilien et al. 1998) are potentially constrained by differences in structure, age and chemistry of the study organisms. By testing Asparagopsis armata grown with and without halogenated metabolites, we demonstrated that these compounds were active in maintaining lower densities of bacteria on the surface of the alga. There was an antibacterial effect on both young (apical) and older (mature) regions, although it is possible that apical effects contributed to the lower bacterial densities on the older region. The filamentous algae, that is, the tetrasporophyte of A. armata and Bostrychia moritziana, had lower densities of bacteria on apical regions than on older regions. However, there was no difference between the bacterial densities on younger and older tissue in the gametophytes of $A$. armata. This could be related to the slower growth rate of the gametophyte, compared to a filamentous alga.

Bacteria isolated from the surface of bromide (-) algae were less tolerant to halogenated metabolites than those isolated from bromide (+) algae. This suggests that the microbial community on metabolite-producing algae includes bacteria that have colonised the surface but are inhibited by the compounds. In the absence of these compounds, the previously inhibited bacteria may out-compete other resident bacteria. If important symbioses between bacteria and macroalgae exist (Fries 1970), then certain bacteria will be more tolerant to algal natural products than others. As Asparagopsis armata releases relatively large amounts of halogenated metabolites, the dominant epiphytic bacteria should have the capacity to tolerate, or even breakdown, such compounds. The implied change in bacterial community structure suggests that the interaction between $A$. armata and its epiphytic bacteria is regulated by halogenated metabolites that limit particular bacteria in addition to reducing total surface density.

There are other mechanisms that may constrain the interpretation of the antibacterial effect seen in Asparagopsis armata. A high growth rate may minimise fouling on young tissue, although the halogenated metabolites were still effective at these actively-growing regions. Alternatively, chemical defence against microbes is not limited to the production of secondary metabolites. Oxidative bursts can provide an effective defence against pathogens that breach the cell walls of some algae (Weinberger \& Friedlander 2000, Bouarab 
et al. 2001). While the 2 major halogenated metabolites of A. armata (bromoform and DBA) were antibacterial, it is possible that other compounds contributed to the observed antibacterial effect of bromide (+) algae. However, the relatively high levels of production and release of bromoform and DBA in particular, strongly imply that these are the principal antibacterial agents of A. armata.

Considering the constant interaction of algae with potential bacterial epibionts, regulating the attachment or growth of bacteria (bacterial fouling) through the production of secondary metabolites may give an alga an ecological advantage (Wahl 1989, Steinberg \& de Nys 2002). For Asparagopsis armata, the determined release of halogenated metabolites, their antibacterial activity against relevant bacteria, and the increased densities of bacteria on the surface of metabolite-free algae, indicated a probable role for these metabolites in defence against epiphytic bacteria. The different effect of the halogenated metabolites on bacteria isolated from metabolite-producing algae compared to bacteria from metabolite-free algae implied an impact beyond a general antibiotic effect. While a large proportion of epiphytic bacteria can be isolated from some seaweeds (Jensen et al. 1996), the non-culturable bacteria on $A$. armata represent a crucial issue for the culture-based component, and the ecological importance of the isolated bacteria remains unknown. Molecular tools that examine community-scale microbial interactions (such as denaturing gradient gel electrophoresis; Dahllöf 2002), will be integral to measuring metabolite-induced changes to the bacterial community, and promise to identify epiphytic bacteria that are ecologically-important and practical for use in manipulative assays.

Acknowledgements. We thank C. Holmström and M. Labbate for the supply of bacterial strains and assistance with bacterial culture techniques; N. Shakibaee for assistance with GCMS; and D. Marshall for discussion on statistical analysis. We are grateful for insightful comments on the manuscript from L. Cole and 3 anonymous reviewers. This work was supported by an Australian Postgraduate Award to N.P.

\section{LITERATURE CITED}

Al-Ogily SM, Knight-Jones EW (1977) Antifouling role of antibiotics produced by marine algae and bryozoans. Nature 265:728-729

Bouarab K, Potin P, Weinberger F, Correa J, Kloareg B (2001) The Chondrus crispus-Acrochaete operculata hostpathogen association, a novel model in glycobiology and applied phycopathology. J Appl Phycol 13:185-193

Cancho B, Ventura F, Galceran MT (1999) Behavior of halogenated disinfection by-products in the water treatment plant of Barcelona, Spain. B Environ Contam Tox 63: 610-617
Correa JA, Sanchez PA (1996) Ecological aspects of algal infectious diseases. Hydrobiologia 326/327:89-95

Dahllöf I (2002) Molecular community analysis of microbial diversity. Curr Opin Biotech 13:213-217

de Nys R, Steinberg PD, Rogers CN, Charlton TS, Duncan MW (1996) Quantitative variation of secondary metabolites in the sea hare Aplysia parvula and its host plant, Delisea pulchra. Mar Ecol Prog Ser 130:135-146

de Nys R, Dworjanyn SA, Steinberg PD (1998) A new method for determining surface concentrations of marine natural products on seaweeds. Mar Ecol Prog Ser 162:79-87

Dworjanyn SA, de Nys R, Steinberg PD (1999) Localisation and surface chemistry of secondary metabolites in the red alga Delisea pulchra. Mar Biol 133:727-736

Fenical W (1975) Halogenation in the Rhodophyta: a review. J Phycol 11:245-259

Fries L (1966) Influence of iodine and bromine on growth of some red algae in axenic culture. Physiol Plantarum 19: 800-808

Fries L (1970) The influence of microamounts of organic substances other than vitamins on the growth of some red algae in axenic culture. Brit Phycol J 5:39-46

Hay ME, Fenical W (1988) Marine-plant herbivore interactions: the ecology of chemical defense. Annu Rev Ecol Syst 19:111-145

Hay ME, Fenical W, Gustafson K (1987) Chemical defense against diverse coral-reef herbivores. Ecology 68: 1581-1591

Hellio C, De La Broise D, Dufosse L, Le Gal Y, Bourgougnon $N$ (2001) Inhibition of marine bacteria by extracts of macroalgae: potential use for environmentally friendly antifouling paints. Mar Environ Res 52:231-247

Hornsey IS, Hide D (1974) The production of antimicrobial compounds by British marine algae I. Antibiotic producing marine algae. Brit Phycol J 9:353-361

Jensen PR, Kauffman CA, Fenical W (1996) High recovery of culturable bacteria from the surfaces of marine algae. Mar Biol 126:1-7

Kubanek J, Jensen PR, Keifer PA, Sullards MC, Collins DW, Fenical W (2003) Seaweed resistance to microbial attack: a targeted chemical defense against marine fungi. Proc Natl Acad Sci USA 100:6916-6921

Kushmaro A, Rosenberg E, Fine M, Loya Y (1997) Bleaching of the coral Oculina patagonica by Vibrio AK-1. Mar Ecol Prog Ser 147:159-165

Kylin H (1927) Uber die Blasenzellen der Flordieen. Bot Not 1927:274-285

Littler MM, Littler DS (1995) Impact of the CLOD pathogen on Pacific coral reefs. Science 267:1356-1360

Manefield M, de Nys R, Kumar N, Read R, Givskov M, Steinberg P, Kjelleberg S (1999) Evidence that halogenated furanones from Delisea pulchra inhibit acylated homoserine lactone (AHL)-mediated gene expression by displacing the AHL signal from its receptor protein. Microbiology 145:283-291

Marshall RA, Harper DB, McRoberts CW, Dring MJ (1999) Volatile bromocarbons produced by Falkenbergia stages of Asparagopsis spp. (Rhodophyta). Limnol Oceanogr 44: 1348-1352

Maximilien R, de Nys R, Holmström C, Gram L, Givskov M, Crass K, Kjelleberg S, Steinberg PD (1998) Chemical mediation of bacterial surface colonisation by secondary metabolites from the red alga Delisea pulchra. Aquat Microb Ecol 15:233-246

McConnell OJ, Fenical W (1977) Halogen chemistry of the red alga Asparagopsis. Phytochemistry 16:367-374

McConnell OJ, Fenical W (1979) Antimicrobial agents from 
marine red algae of the family Bonnemaisoniaceae. In: Hoppe HA, Levring T, Tanaka Y (eds) Marine algae in pharmaceutical science. Walter de Gruyter, New York, p 403-427

McKey D (1979) The distribution of secondary compounds within plants. In: Rosenthal GA, Janzen DH (eds) Herbivores: their interaction with secondary plant metabolites. Academic Press, New York, p 55-133

McLachlan J (1977) Effects of nutrients on growth and development of embryos of Fucus edentatus (Phaeophyceae, Fucales). Phycologia 16:329-338

Nightingale PD, Malin G, Liss PS (1995) Production of chloroform and other low molecular weight halocarbons by some species of macroalgae. Limnol Oceanogr 40: 680-689

Paul NA, Cole L, de Nys R, Steinberg PD (in press) Ultrastructure of the gland cells of the red alga Asparagopsis armata (Bonnemaisoniaceae). J Phycol

Potin P, Bouarab K, Salaün J, Pohnert G, Kloareg B (2002) Biotic interactions of marine algae. Curr Opin Plant Biol 5:1-10

Provasoli L (1968) Media and prospects for the cultivation of marine algae. In: Watanabe A, Hattori A (eds) Culture and collections of algae. Proceedings of the US-Japanese Conference, Hakone, Japanese Society of Plant Physiology, Tokyo, p 63-75

Quinn GP, Keough MJ (2002) Experimental design and data analysis for biologists. Cambridge University Press, Cambridge

Schmitt TM, Hay ME, Lindquist N (1995) Constraints on chemically mediated coevolution: multiple functions for seaweed secondary metabolites. Ecology 76:107-123

Schoenwaelder MEA (2002) The occurrence and cellular

Editorial responsibility: Howard I. Browman

(Associate Editor-in-Chief), Storebø, Norway significance of physodes in brown algae. Phycologia 41: 125-39

Sieburth JM, Conover JT (1965) Sargassum tannin, an antibiotic that retards fouling. Nature 208:52-53

Steinberg PD, de Nys R (2002) Chemical mediation of colonization of seaweed surfaces. J Phycol 38:621-629

Wahl M (1989) Marine epibiosis. I. Fouling and antifouling: some basic aspects. Mar Ecol Prog Ser 58:175-189

Wahl M, Jensen PR, Fenical W (1994) Chemical control of bacterial epibiosis on ascidians. Mar Ecol Prog Ser 110: 45-57

Weinberger F, Friedlander M (2000) Response of Gracilaria conferta (Rhodophyta) to oligoagars results in defense against agar-degrading epiphytes. J Phycol 36:1079-1086

Wolk CP (1968) Role of bromine in the formation of the refractile inclusions of the vesicle cells of the Bonnemaisoniaceae (Rhodophyta). Planta 78:371-378

Woolard FX, Moore RE, Roller PP (1979) Halogenated acetic and acrylic acids from the red alga Asparagopsis taxiformis. Phytochemistry 18:617-620

Young DN (1978) Ultrastructural evidence for a secretory function in the gland cells of the marine red alga Botryocladia pseudodichotoma (Rhodymeniaceae). Protoplasma 94:109-126

Young DN (1979) Fine structure of the 'gland cells' of the red alga Opuntiella californica (Soleriaceae, Gigartinales). Phycologia 18:288-295

Young DN, West JA (1979) Fine structure and histochemistry of the vesicle cells of the red alga Antithamnion defectum (Ceramiaceae). J Phycol 15:49-57

Young DN, Howard BM, Fenical W (1980) Subcellular localization of brominated secondary metabolites in the red alga Laurencia snyderae. J Phycol 16:182-185

Submitted: April 1, 2005; Accepted: June 16, 2005 Proofs received from author(s): November 21, 2005 